\title{
Diallel analysis of cowpea (Vigna unguiculata (L.) Walp.) for some physical properties of seed under the Sudano-guinean conditions
}

\author{
Jean-Baptiste Noubissié Tchiagam ${ }^{1^{*}}$, Joseph Martin Bell ${ }^{2}$, Doris Flore Ngakeu $^{1}$, Nicolas \\ Yanou Njintang ${ }^{1}$ and Emmanuel Youmbi ${ }^{2}$ \\ ${ }^{1}$ University of Ngaoundéré, Faculty of Science, Department of Biological Sciences, P.O. Box \\ 454 Ngaoundéré, Cameroon. \\ ${ }^{2}$ University of Yaoundé I, Faculty of Science, Department of Plant Biology, Unit of Genetics \\ and Biotechnology, P.O. Box 812 Yaoundé, Cameroon.
}

\begin{abstract}
The present study was undertaken at Dang (soudano-guinean zone of Cameroon) to determine the variability of 100-seed weight, geometric surface, porosity and sphericity of the seeds of 10 cowpea (Vigna unguiculata) genotypes and investigate the genetic basis of these characters through a $5 \times 5$ half-diallel cross mating. Knowledge of the physical properties of the seed of cowpea was necessary for the design of equipment for transporting, sorting, cleaning, separating, smashing and processing it into different foods. The experimental design was a randomized complete block with three replicates. Analysis of results showed that these genotypes presented a significant variability for the four physical properties. The average properties of seed were found to be a hundred seed mass of $20.46 \mathrm{~g}$, a surface area of $0.84 \mathrm{~cm}^{2}$, a sphericity of $35.50 \%$ and a porosity of 0.65 . Genetic analysis demonstrated that the parents differed for their general combining ability (GCA) and the crosses showed specific combining ability (SCA). These physical parameters were highly heritable with broad-sense heritability $\left(h^{2}\right)$ values ranged from 0.76 to 0.96 suggesting that genetic advance was expected. Both dominant and additive gene effects were significant for all traits with a predominance of additive genes for seed mass and dominant genes for degree of sphericity. The alleles for seed weight, degree of porosity and sphericity were mostly recessive whereas the higher performances for seed surface where due to the presence of dominant alleles. Heterosis in $F_{1}$ over best parent was recorded for some combinations. For these traits, recurrent selection might be a useful breeding strategy.
\end{abstract}

Keywords: Vigna unguiculata (L.) Walp., Sudano-guinean zone, seed physical properties, diallel analysis, genetic improvement.

\section{INTRODUCTION}

Cowpea (Vigna unguiculata [L.] Walp.), one of the most widely adapted, versatile, and nutritious grain legumes in the hot regions of Africa, Asia and the Americas, constitutes one of the principal source of plant protein in northern Cameroon (Hall et al., 2003; Noubissié et al., 2007). V. unguiculata which in older references may be identified as $V$. sinensis, is grown on about 12.5 million ha in warm to hot regions of the world (Ehlers and Hall, 1997). Annual global production is about 4 million tons (Hall et al, 2003). Dry seeds for human consumption are the principal product of the plant, but leaves, fresh peas, and fresh green pods are consumed by many poor people who do not have access to broadly based diet by many poor people who do not have access to broadly based diet (Hall et al., 2003; Langyintuo et al., 2003). Cowpea has potential of becoming an industrial crop and widespread consumption of convenience foods containing significant amounts of cowpea substantially increased the demand and value of cowpea seed (Hall et al., 2003; Ajeigbé et al., 2008). Mohsenin (1970) noted that an understanding of the physical laws governing the responses of the biological material to various handling and processing methods is a fundamental requirement in the design of machines for handling them. Knowledge of the physical properties of $V$. unguiculata seed, which is processed into an array of traditional foods ("akara","moin-moin", "koki"), is necessary for the design of equipment for harvesting, transporting, sorting, cleaning, separating, smashing, extracting and processing it into different foods (Kabas et al., 2007; Maundé et al., 2007). Threshing of cowpea is one of the most important steps in its processing and normally done manually. Recent studies also try to incorporate computer modeling to aid in the process of threshing with machine (Maunde et al., 2007). 
Agric. Biol. J. N. Am., 2011, 2(4): 698-707

These physical properties affect the conveying characteristics of solid materials by air or water and cooling and heating loads of food materials (Unal et al., 2006). For instance, sphericity is one of the most important properties because it affects how easily cowpea can be processed by the food industry (Kabas et al., 2001). Seed index (weight of 100 seeds) directly influences the productivity and determines grain quality for commercialization and also the seed vigor (Drabo et al., 1984; Lopez et al., 2003, Rahman et al., 2005). According to Ehlers and Hall (1997), in cowpea, the consumer shows preference for a seed standard from medium to large (15 to $30 \mathrm{~g}$ ). The volume and density of the seeds play an important role in numerous technological processes and in the evaluation of product quality (Taiwo, 1998). Therefore, to produce seed of a specific size, and to meet a specific market demand, a better understanding of the inheritance pattern and gene interactions that govern physical traits is required along with an understanding of potential environmental influence. Variations in cowpea seed physical properties among varieties were found by Drabo et al. (1984), Taiwo (1998), Olapade et al. (2002), Lopes et al. (2003), Unal et al. (2006), Kabas et al. (2007), Maunde et al. (2007), Noubissié et al. (2007) and Kaptso et al. (2008). Many studies have reported on the physical properties of grains or seeds of plants, such as pea (Gupta et al., 1984; Yalcin et al., 2007), cumin (Singh and Goswami, 1996), bambara groundnuts (Baryeh, 2001), cotton (Ozarslan, 2002; Rahman et al., 2005), sesame (Tunde-Akintunde and Akintunde, 2004), vetch (Yalcin and Ozarslan, 2004), safflower (Baumer et al., 2006), dry beans (Ceyhan, 2006), rice (Thakur and Gupta, 2006) and chickpea (Konak et al., 2002; Hossain et al., 2010). However, research on the genetics of these properties is limited until now. Proper understanding of genetic mechanisms involving in expression of these physical characters would help in planning effective breeding strategies. The purpose of the present study was to evaluate in cowpea the varietal differences and assess through diallel analysis the genetic control of four main physical properties; so that the quality of the seed can be genetically improved.

\section{MATERIALS AND METHODS}

Study site : The research was carried out during the year's 2008 to 2009 at the University of Ngaoundéré campus $\left(1113 \mathrm{~m}\right.$ altitude, $7.28^{\circ} \mathrm{N}$ latitude and $13.34^{\circ} \mathrm{E}$ longitude), which is located at Dang, a village of Ngaoundéré in the Adamawa region, Cameroon. This region belongs to the high altitude
Guinean savannah ecological zone. The climate is characterized by two seasons: a rainy season (April October) and a dry season (November - March). The annual rainfall is about $1500 \mathrm{~mm}$. The mean annual temperature is $22^{\circ} \mathrm{C}$, while the annual humidity is about $70 \%$. The soil is ferruginous type, developed on basalt, with $9.4 \mathrm{mg} \mathrm{kg}^{-1}$ organic matter, ratio $\mathrm{C} / \mathrm{N}=$ 0.33 and $\mathrm{pH} 5.2$.

Biological material and experimental plots: Ten cowpea homozygous varieties including seven local landraces and three improved lines obtained from the Institute of Agricultural Research for Development (IRAD Maroua and Foumbot stations) were used for the study (Table 1). A preliminary field trial was conducted during the 2008 growing season to evaluate their genetic variability. The seeds of the entries were sown in a randomized complete block design (RCBD) with three replications. Sowing took place on May 06, 2008, on an experimental surface of $75 \mathrm{~m}^{2}(10.5 \mathrm{~m}$ length $\times 7 \mathrm{~m}$ broad). Each plot unit consisted on one row of $3 \mathrm{~m}$ length $\times 0.35 \mathrm{~m}$ broad, spaced $30 \mathrm{~cm}$ apart. Three seeds of each variety were sown at an intra-row spacing of $25 \mathrm{~cm}$ and thinned to one per hill, 20 days after sowing (DAS). The plots were manually weeded at 20 DAS, 40 DAS and at 60 DAS. At flowering stage, plots were sprayed with a standard insecticide formulation, cypermethrin + dimethoate at the rate $30 \mathrm{~g}+250 \mathrm{~g}$ a.i $/ \mathrm{L}$, to control pod borers and flower midges. A mineral fertiliser $\left(7 \% \mathrm{~N} ; 14 \% \mathrm{P}_{2} \mathrm{O}_{5} ; 7 \% \mathrm{~K}_{2} \mathrm{O}\right)$ was applied to the seedlings three weeks after planting at rate of $60 \mathrm{~kg}$ per ha. A maturity, harvesting was done at four-day intervals, when the pods were ready for picking. Seeds were separated from dry pods.

Five genotypes which were chosen based on their genetic variation for these traits and planted in pots from September to December 2008 for crossings. Six plastic pots containing farm soil, farmyard manure and sand at ratio of $3: 1: 1$, were used for each parent and two seeds were planted per pot. At flowering, manual crossings were carried out with emasculation to provide $F_{1}$ generation. A $5 \times 5$ half-diallel mating was obtained giving 15 combinations consisting of five parents $(n)$ and $10 F_{1}$ hybrids [n (n-1)/2]. The five parental along with the $10 \mathrm{~F}_{1}$ hybrids obtained were planted in field in RCBD with three replications during the rainy season 2009. Sowing took place on April 15,2009 , at the beginning of the rainy season on an experimental surface of $105 \mathrm{~m}^{2}(10.5 \mathrm{~m} \times 10 \mathrm{~m})$. Plot unit size, spacing, weeding, treatments and harvesting were as previous described for variability study. 
Agric. Biol. J. N. Am., 2011, 2(4): 698-707

Table 1. Origin and description of cowpea genotypes

\begin{tabular}{|c|c|c|c|c|c|}
\hline Genotypes & Origin & Growth & Seed & Testa & $\begin{array}{l}\text { Moisture content } \\
(\%)\end{array}$ \\
\hline BA (Bafia) & Local & Erect & Violet & smooth & $9.24 \pm 0.40$ \\
\hline BR1 & IRAD & Erect & White & rough & $10.14 \pm 0.25$ \\
\hline CRSP (CRSP) & IRAD/CRSP & prostrate & White & rough & $9.84 \pm 0.90$ \\
\hline HM (Hadiam Marva) & Local & prostrate & White & rough & $11.60 \pm 0.66$ \\
\hline HMO (Hadiam Mouchiche) & Local & Erect & White & rough & $11.75 \pm 0.50$ \\
\hline HALG (Halagare Gongourdem) & Local & prostrate & White & rough & $10.80 \pm 0.50$ \\
\hline HALM (Halagare Memedem) & Local & prostrate & White & rough & $10.60 \pm 0.33$ \\
\hline Hoyo (Hoyo Hoyo) & Local & prostrate & White & rough & $11.45 \pm 0.66$ \\
\hline 573 (IT97K-573-1-1) & IITA & erect & White & rough & $10.02 \pm 0.90$ \\
\hline NH (Niébé Hosseré) & Local & prostrate & White & rough & $9.20 \pm 0.82$ \\
\hline
\end{tabular}

CRSP: Collaborative Research Support Program; IITA: International Institute of Tropical Agriculture; IRAD: Institute of Agricultural Research for Development (Maroua regional Center)

Physical properties: The cowpea seed were kept in cooled bags for transport to the laboratory. The seeds were cleaned in an air screen cleaner to remove all foreign matter such as dust, dirt and chaff as well as immature and damaged seeds. The initial moisture content of the seeds was preliminary determined by drying at $105^{\circ} \mathrm{C}$ for $24 \mathrm{~h}$ (Yalcin and Ozarslan, 2004).

The 100-seed mass was measured by using an electronic balance of $0.001 \mathrm{~g}$ sensitivity (Sartorius Prodilab, France).

The sphericity and the surface area of cowpea seeds were calculated according to Mohsenin (1970) and Baryeh (2001). For each replication, 50 seeds were selected at random per genotype and their individual length $(L)$, width $(W)$ and thickness $(T)$ were measured from three main dimensions which are in three perpendicular directions using a micrometer gauge reading to $0.01 \mathrm{~mm}$ (Junior Chrome Mat Roch / France). $L$ was defined as the distance from the eye's seed to opposite end, while $W$ and $T$ taking in two opposite perpendicular direction of eye seed represented the major and minor seed diameters. The average diameter of seed was calculated by using the geometric mean $D_{g}$ of the three axial dimensions. $D_{g}$ was calculated by using the following relationship (Unal et al., 2006).

$\mathrm{D}_{\mathrm{g}}=(L W T)^{1 / 3}$

The surface area $(S)$ of cowpea seed was found by analogy with a sphere of same geometric mean diameter, using the following equation.

$S=\pi \cdot D_{g}^{2} \quad\left(\mathrm{~cm}^{2}\right)$

The sphericity $(\varphi)$ cowpea of seeds was estimated by using the following relationship.

$\varphi=D_{g} / L$

The percentage porosity $(\varepsilon)$ which is the fraction of the space in the bulk seeds which is not occupied by the grains, was determined by the following equation (Unal et al., 2006).

$\varepsilon=100\left[\left(1-\rho_{\mathrm{b}}\right) / \rho_{\mathrm{f}}\right](\%)$

Where: $\rho_{b}$ is the bulk density in $\mathrm{g} \mathrm{ml}^{-1}$ and $\rho_{\mathrm{f}}$ is the seed density in $\mathrm{g} \mathrm{ml}^{-1}$.

Seed true density $\left(\rho_{f}\right)$ was measured by the liquid displacement method using sample of 25 seeds (Mohsenin, 1970, Yalcin and Ozarslan, 2004). The volume of liquid displaced was found by immersing weighed seeds in the toluene (C7H8). The bulk density $\rho_{b}$ was determined according to the standard test weight procedure by filling a container of $500 \mathrm{ml}$ with the seeds from the height of $150 \mathrm{~mm}$ at a constant rate and then weighing the content (Baryeh, 2001).

Genotypic variability for studied traits: For each genotype, the physical properties were studied in three replicates. Data of the 10 pure lines were subjected to ANOVA using computer program STATGRAPHICS PLUS. The genotypic means were compared using Least Significant Difference at 5\% level of probability (LSD 5\%).

Genetic analysis: The genetic analysis was done from the $5 \times 5$ half-diallel mating using DIALL microcomputer package (Ukai, 1989). The Griffing's (1956) method 2 (excluding reciprocal $F_{1}$ crosses), model 1 (fixed effects) was used to analyze the GCA of lines and the SCA of crosses. The analysis of 
variance by Walters and Morton (1978) was used for the study of inheritance of the characters. The genetic parameters were estimated as per Hayman (1954). With this approach, the components of variation were partitioned into the additive effects $(a)$ and the dominance effect ( $b$ which is further subdivided into $b 1, b 2$ and $b 3$ ). Heritability in broad sense $\left(h^{2}\right)$ was measured as the proportion of genetic variance of homozygous parents $\left(\sigma^{2}{ }_{g}\right)$ in the phenotypic variance between parents $\left(\sigma_{p}^{2}\right)$, while heritability in narrow sense $\left(\mathrm{h}^{2}{ }_{n}\right)$ was calculated as the proportion of additive variance $\left(\sigma^{2}{ }_{A}\right)$ in the phenotypic variance $\left(\sigma_{p}^{2}\right)$ (Mather and Jinks 1971). Heterobeltiosis (HB \%) was estimated as deviation of $F_{1}$ value $\left(F_{1}\right)$ from the better parent value (BP) as suggested by Fonsecca and Patterson (1968). The following formula was used: $\mathrm{HB} \%=[(\mathrm{F} 1-\mathrm{MP}) / \mathrm{MP}]$ $x$ 100. Significance of $H B \%$ was by ' $t$ ' test using SE value.

Table 2. Genotypic variability of cowpea genotypes for seed physical properties

\begin{tabular}{|l|c|c|c|c|}
\hline \multicolumn{1}{|c|}{ Genotypes } & Weight (g) & $\begin{array}{c}\text { Geometric surface } \\
\left(\mathbf{c m}^{\mathbf{2}}\right)\end{array}$ & Porosity (\%) & Degree of sphericity \\
\hline BA & $17.00 \pm 0.47^{\mathrm{d}}$ & $0.62 \pm 0.15^{\mathrm{e}}$ & $25.54 \pm 4.92^{\mathrm{e}}$ & $0.55 \pm 0.11^{\mathrm{de}}$ \\
\hline BR1 & $21.02 \pm 0.29^{\mathrm{c}}$ & $0.88 \pm 0.29^{\mathrm{cd}}$ & $37.48 \pm 4.10^{\mathrm{c}}$ & $0.68 \pm 0.12^{\mathrm{b}}$ \\
\hline CRSP & $16.51 \pm 0.53^{\mathrm{d}}$ & $0.71 \pm 0.26^{\mathrm{cde}}$ & $30.91 \pm 3.08^{\mathrm{d}}$ & $0.65 \pm 0.06^{\mathrm{bcd}}$ \\
\hline HM & $15.35 \pm 0.27^{\mathrm{d}}$ & $0.35 \pm 0.08^{\mathrm{f}}$ & $50.75 \pm 2.92^{\mathrm{a}}$ & $0.42 \pm 0.08^{\mathrm{f}}$ \\
\hline HMO & $23.58 \pm 0.36^{\mathrm{b}}$ & $1.40 \pm 0,40^{\mathrm{a}}$ & $33.70 \pm 4.86^{\text {cd }}$ & $0.86 \pm 0.12^{\mathrm{a}}$ \\
\hline HALG & $19.66 \pm 0.45^{\mathrm{c}}$ & $0.66 \pm 0.12^{\mathrm{de}}$ & $17.75 \pm 1.31^{\mathrm{f}}$ & $0.63 \pm 0.10^{\mathrm{cde}}$ \\
\hline HALM & $25.06 \pm 0.37^{\mathrm{a}}$ & $1.14 \pm 0.28^{\mathrm{b}}$ & $34.32 \pm 3.82^{\mathrm{cd}}$ & $0.81 \pm 0.26^{\mathrm{a}}$ \\
\hline Hoyo & $23.10 \pm 0.94^{\mathrm{b}}$ & $0.96 \pm 0.13^{\mathrm{bc}}$ & $47.34 \pm 3.20^{\mathrm{ab}}$ & $0.67 \pm 0,09^{\mathrm{bc}}$ \\
\hline NH & $19.60 \pm 0.39^{\mathrm{c}}$ & $0.56 \pm 0.18^{\mathrm{ef}}$ & $42.93 \pm 2.77^{\mathrm{b}}$ & $0.53 \pm 0.06^{\mathrm{e}}$ \\
\hline 573 & $23.75 \pm 0.23^{\mathrm{b}}$ & $1.15 \pm 0,33^{\mathrm{b}}$ & $30.20 \pm 5,18^{\mathrm{de}}$ & $0.72 \pm 0.08^{\mathrm{b}}$ \\
\hline Mean & $20.46 \pm 1.28$ & $0.84 \pm 0.16$ & $35.50 \pm 3.84$ & $0.65 \pm 0,07$ \\
\hline LSD (0.05) & 1.65 & 0.21 & 4.76 & 0.08 \\
\hline
\end{tabular}

Means with the same subscript within the same column are not significantly different at $p<0.05$; LSD (0.05): Least significant difference at $5 \%$ level of probability.

Genetic analysis of physical properties: The ANOVA of the $5 \times 5$ half-diallel mating with Walters and Morton's (1978) method showed the significance of genotypic effects and their components (Table 3 ). Both additive (a) and dominant effects (b) were all significant $(p<0.05)$. Within $(b)$, the mean dominance effects $\left(b_{1}\right)$ were significant only for seed weight while the additional dominance effects due to the parents $\left(b_{2}\right)$ appeared non significant only for the degree of porosity. The residual dominance effects $\left(b_{3}\right)$ were also highly significant $(p<0.01)$ for the four physical traits.

For each physical trait, the genetic parameters (average degree of dominance, direction of

\section{RESULTS AND DISCUSSIONS}

\section{RESULTS}

\section{Genotypic variation for seed physical properties}

Analysis of variance indicated significant differences between the genotypes for all the investigated characteristics (Table 2). The values of 100-seed weight ranged from 15.35 for HM to $25.06 \mathrm{~g}$ for HALM $($ mean $=20.46 \mathrm{~g})$. The geometric surface of seed ranged from $0.35(\mathrm{HM})$ to $1.40 \mathrm{~cm}^{2}(\mathrm{HMO})$ (mean $=$ $0.84 \%$ ). The degree of porosity was high for lines HM and Hoyo, and varied from 17.75 to $50.75 \%$ (mean = $35.30 \%$ ). The values of sphericity were calculated by using data on geometric mean diameter and the major axis of the seed. Results indicated that the sphericity of the seed ranged from 0.42 to $0.86 \%$ and seeds of varieties HMO and HALM showed the highest percentages for this trait. 
varied from - 0.311 for surface area to 0.96 for seed weight. The correlation between parental values $(\mathrm{Pr})$ and recessive factor $(\mathrm{Wr}+\mathrm{Vr})$ was positive but non significant for seed weight $(r=0.64)$, positive and significant for porosity $(r=0.96)$ and sphericity $(r=$ $0.92)$, but negative for seed surface $(r=-0.93)$ (Table 4).

The analysis of variance based on Griffing's (1956) method showed that the mean squares of GCA and Table 3. Computation of mean squares for ANOVA of $5 \times 5$ half diallel for physical properties of cowpea seed.

\begin{tabular}{|c|c|c|c|c|c|}
\hline \multirow[t]{2}{*}{ Source } & \multirow[t]{2}{*}{ Df } & \multicolumn{4}{|c|}{ Mean squares for physical properties of cowpea seed } \\
\hline & & 100 seeds weight & Geometric surface & Degree of porosity & Degree of sphericity \\
\hline Block & 2 & $0.62^{\mathrm{ns}}$ & $42.77^{\mathrm{ns}}$ & $0.97^{\text {ns }}$ & $0.76^{\mathrm{ns}}$ \\
\hline$a$ & 4 & $683.17^{\star \star}$ & $2682.19^{\star *}$ & $112.66^{* \star}$ & $212.38^{* \star}$ \\
\hline b & 10 & $67.90^{* *}$ & $1755.22^{* *}$ & $96.33^{* *}$ & $209.66^{* \star}$ \\
\hline $\mathrm{b}_{1}$ & 1 & $437.63^{\star \star}$ & $46.80^{\text {ns }}$ & $33.88^{\mathrm{ns}}$ & $29.14^{\mathrm{ns}}$ \\
\hline$b_{2}$ & 4 & $294.07^{* *}$ & $1197.80^{* *}$ & $196.12^{\mathrm{ns}}$ & $606.18^{\star *}$ \\
\hline$b_{3}$ & 5 & $186.98^{* \star}$ & $2542.83^{\star *}$ & $212.49^{* \star}$ & $139.42^{* *}$ \\
\hline Error & 28 & 3.48 & 71.10 & 22.44 & 39.3 \\
\hline
\end{tabular}

$a=$ additive effects of genes; $b=$ dominant effects of genes; $b_{1}=$ mean dominance effects; $b_{2}=$ additional dominance deviation due to the parents, $b_{3}=$ residual dominance effects, ${ }^{\text {ns }}$ indicates non significance at $5 \%$, ${ }^{* *}$ indicates significance at $1 \%$.

Table 4. Genetic components estimates and heritability values for cowpea seed physical properties based on a 5 x 5 half-diallel.

\begin{tabular}{|l|l|l|l|l|}
\hline Genetic parameter & $\mathbf{1 0 0}$ seeds weight & $\begin{array}{l}\text { Geometric } \\
\text { surface }\end{array}$ & Degree of porosity & $\begin{array}{l}\text { Degree of } \\
\text { sphericity }\end{array}$ \\
\hline $\begin{array}{l}\text { Average degree of dominance } \\
\left(\mathrm{H}_{1} / \mathrm{D}\right)^{1 / 2}\end{array}$ & 0.31 & 1.77 & 0.68 & 0.79 \\
\hline Direction of dominance $(\mathrm{h})$ & -1.89 & +2.04 & -1.22 & -0.55 \\
\hline Broad sense heritability $\left(\mathrm{h}^{2}\right)$ & 0.90 & 0.96 & 0.88 & 0.76 \\
\hline Narrow sense heritability $\left(\mathrm{h}^{2} \mathrm{n}\right)$ & 0.67 & 0.41 & 0.43 & 0.26 \\
\hline Regression $(\mathrm{Vr}, \mathrm{Wr})$ & $0.96 \mathrm{Vr}+4.15$ & $-0.31 \mathrm{Vr}+376.65$ & $0.71 \mathrm{Vr}+516.21$ & $0.74 \mathrm{Vr}+0.08$ \\
\hline $\mathrm{r}(\mathrm{Pr}, \mathrm{Wr}+\mathrm{Vr})$ & $+0.64 \mathrm{~ns}$ & $-0.93^{* *}$ & $0.96^{* *}$ & $0.92^{* *}$ \\
\hline Regression $(\mathrm{Pr}, \mathrm{Vr}+\mathrm{Wr})$ & $6.32 \mathrm{Pr}-189.7$ & $\begin{array}{c}-10.01 \mathrm{Pr}+ \\
1656.2\end{array}$ & $66.55 \mathrm{Pr}-147.4$ & $1.23 \mathrm{Pr}+0.02$ \\
\hline
\end{tabular}

$\mathrm{r}(\mathrm{Pr}, \mathrm{Wr}+\mathrm{Vr})$ : Correlation between the degree of dominance of the parents $(\mathrm{Wr}+\mathrm{Vr})$ and the parental value $(\mathrm{Pr}), \mathrm{ns}: \mathrm{not}$ significant, * Significant at the $5 \%$ level.

Table 5. ANOVA for combining ability of physical properties of seed in $5 \times 5$ half-diallel cross of cowpea

\begin{tabular}{|c|c|c|c|c|c|}
\hline \multirow[t]{2}{*}{ Source } & \multirow[t]{2}{*}{ Df } & \multicolumn{4}{|c|}{ Mean squares of seed physical properties } \\
\hline & & Seed weight & Geometric surface & Porosity & Degree of sphericity \\
\hline GCA & 4 & $204.95^{\star *}$ & $1254.58^{\star *}$ & $101.46^{\star \star}$ & $37.65^{\star \star}$ \\
\hline SCA & 5 & $57.62^{\star \star}$ & $367.50^{\star *}$ & $42.63^{* *}$ & $47.70^{* *}$ \\
\hline Error & 18 & 2.74 & 43.42 & 2.46 & 1.21 \\
\hline \multicolumn{2}{|c|}{$\sigma^{2} \mathrm{GCA} / \sigma^{2} \mathrm{SCA}$} & 27.00 & 1.46 & 1.79 & 0.61 \\
\hline
\end{tabular}

GCA: variation due to general combining ability; SCA: variation due to specific combining ability; Error: error variation or interaction between the replication and genotypes; $\sigma^{2}$ GCA: variance of general combining ability; $\sigma^{2} S C A$ : variance of specific combining ability; *and ** indicates significance at $\mathrm{P} \leq 0.05$ and $\mathrm{P} \leq 0.01$ respectively. 
The estimates of GCA effects of the various parents for seed physical properties (Table 6) revealed that BR1, NH and 573 had positive significant values for seed weight; $\mathrm{HM}$ and CRSP had positive significant values for geometric surface; $\mathrm{NH}$ and $\mathrm{HM}$ presented significant positive GCA for degree of porosity while CRSP, BR1 and 573 showed positive significant values for sphericity. Genotypes $\mathrm{HM}$ and $\mathrm{NH}$ exhibited significant negative GCA for degree of sphericity while CRSP and BR1 showed significant negative values for porosity. Globally, the parents studied possessed high proportion of dominant genes for these physical traits (Table 6).

Table 6. Predicted General Combining Ability effects (GCA) and proportion of dominant genes for seed physical properties of five cowpea cultivars

\begin{tabular}{|c|c|c|c|c|c|c|c|c|}
\hline \multirow[t]{3}{*}{ Parents } & \multicolumn{8}{|c|}{ GCA effects and proportion of dominant genes } \\
\hline & \multicolumn{2}{|c|}{$\begin{array}{c}\text { Seed } \\
\text { Weight }\end{array}$} & \multicolumn{2}{|c|}{ Geometric surface } & \multicolumn{2}{|c|}{ Porosity } & \multicolumn{2}{|c|}{ Degree of sphericity } \\
\hline & GCA & \%D & GCA & \%D & GCA & \%D & GCA & \%D \\
\hline CRSP & -3.92 & 8.90 & +6.00 & 75.47 & $-2.67^{* \prime}$ & 58.92 & $+1.00^{*}$ & 51.12 \\
\hline BR1 & +1.96 " & 95.50 & $-4.86^{\star \star}$ & 49.25 & $-1.51^{*}$ & 45.60 & $+1.55^{\star *}$ & 65.00 \\
\hline $\mathrm{HM}$ & -0.30 & 82.00 & +7.20 & 62.90 & $+1.8^{* *}$ & 29.67 & $-1.66^{* *}$ & 46.23 \\
\hline $\mathrm{NH}$ & $+0.86^{* *}$ & 90.55 & $-5.67^{* *}$ & 40.54 & +2.30 & 21.15 & $-2.73^{* *}$ & 39.36 \\
\hline 573 & +1.40 & 83.43 & -2.67 & 78.23 & +0.06 & 54.88 & $+1.84^{* *}$ & 67.66 \\
\hline SE & 0.29 & & 1.03 & & 0.35 & & 0.19 & \\
\hline
\end{tabular}

*Significant at $p=0.05$ and ** Significant at $p=0.01 ; \% D$ : proportion of dominant genes; SE: Standard error.

Table 7. Estimation of specific combining ability (SCA) and heterobeltiosis (HB \%) for physical properties of seed in ten cowpea crosses.

\begin{tabular}{|c|c|c|c|c|}
\hline Hybrid combination & Seed weight & Geometric surface & Porosity & Degree of sphericity \\
\hline BR1 x CRSP & $\begin{array}{c}-2.88^{\star *} \\
\left(-14.5^{\star *}\right)\end{array}$ & $\begin{array}{l}-4.83^{*} \\
\left(-9.6^{\star}\right)\end{array}$ & $\begin{array}{c}-4.66^{\star *} \\
\left(-20.2^{* *}\right)\end{array}$ & $\begin{array}{c}-0.33^{*} \\
\left(-12.6^{* *}\right)\end{array}$ \\
\hline BR1 x HM & $\begin{array}{c}-3.88^{* *} \\
\left(-16.50^{\star *}\right)\end{array}$ & $\begin{array}{l}-1.60^{*} \\
(-0.43)\end{array}$ & $\begin{array}{l}9.48^{* *} \\
\left(6.5^{\star}\right)\end{array}$ & $\begin{array}{c}-0.45^{*} \\
\left(-22.1^{* *}\right)\end{array}$ \\
\hline BR1 x 573 & $\begin{array}{c}-0.91^{*} \\
\left(-10.5^{\star *}\right)\end{array}$ & $\begin{array}{l}-1.33^{*} \\
\left(-8.6^{*}\right)\end{array}$ & $\begin{array}{c}-4.57^{\star *} \\
\left(-28.7^{* *}\right)\end{array}$ & $\begin{array}{c}-3.33^{\star \star} \\
\left(-19.6^{\star \star}\right)\end{array}$ \\
\hline BR1 $\times$ NH & $\begin{array}{c}0.82 \\
\left(-15.3^{* *}\right)\end{array}$ & $\begin{array}{c}5.00^{\star} \\
\left(19.4^{\star}\right)\end{array}$ & $\begin{array}{c}-0.38 \\
\left(-10.9^{* *}\right)\end{array}$ & $\begin{array}{c}-0.68^{*} \\
\left(-18.6^{\star *}\right)\end{array}$ \\
\hline CRSP $\times$ HM & $\begin{array}{c}0.56 \\
\left(-9.8^{* \star}\right)\end{array}$ & $\begin{array}{c}7.81^{* \star} \\
\left(13.3^{\star \star}\right)\end{array}$ & $\begin{array}{c}-6.88^{* *} \\
\left(-41.5^{* *}\right)\end{array}$ & $\begin{array}{c}1.97^{* *} \\
\left(22.1^{* *}\right)\end{array}$ \\
\hline CRSP x 573 & $\begin{array}{l}-2.66^{* *} \\
\left(-9.6^{* *}\right)\end{array}$ & $\begin{array}{l}-4.83^{* *} \\
\left(-16.0^{\star}\right)\end{array}$ & $\begin{array}{l}-0.38 \\
\left(-8.3^{* *}\right)\end{array}$ & $\begin{array}{c}1.06^{\star} \\
\left(-5.7^{*}\right)\end{array}$ \\
\hline CRSP $\times \mathrm{NH}$ & $\begin{array}{c}2.43^{\star *} \\
\left(10.5^{\star \star}\right)\end{array}$ & $\begin{array}{c}-1.63^{*} \\
\left(-10.1^{* *}\right)\end{array}$ & $\begin{array}{c}4.28^{*} \\
\left(-8.4^{* *}\right)\end{array}$ & $\begin{array}{c}0.05 \\
\left(-13.7^{\star \star}\right)\end{array}$ \\
\hline HM $\times 573$ & $\begin{array}{c}-0.91 \\
\left(-9.3^{\star \star}\right)\end{array}$ & $\begin{array}{c}-3.69^{* *} \\
\left(-21.4^{* \star}\right)\end{array}$ & $\begin{array}{c}-5.43^{*} \\
\left(-25.9^{* *}\right)\end{array}$ & $\begin{array}{c}-0.08 \\
\left(-9.8^{\star *}\right)\end{array}$ \\
\hline $\mathrm{HM} \times \mathrm{NH}$ & $\begin{array}{l}1.20^{*} \\
(4.8)\end{array}$ & $\begin{array}{l}-5.01^{*} \\
\left(-9.5^{\star \star}\right)\end{array}$ & $\begin{array}{c}-2.71^{*} \\
\left(-14.7^{* *}\right)\end{array}$ & $\begin{array}{c}0.21 \\
\left(-13.3^{\star \star}\right)\end{array}$ \\
\hline $573 \times \mathrm{NH}$ & $\begin{array}{c}-1.16^{*} \\
\left(-10.3^{* *}\right)\end{array}$ & $\begin{array}{l}0.83 \\
(6.3)\end{array}$ & $\begin{array}{c}-2.02 \\
\left(-14.9^{* \star}\right)\end{array}$ & $\begin{array}{c}1.88^{\star \star} \\
\left(24.5^{\star \star}\right)\end{array}$ \\
\hline SE & $\begin{array}{c}0.97 \\
(3.08)\end{array}$ & $\begin{array}{c}1.13 \\
(4.56)\end{array}$ & $\begin{array}{l}0.73 \\
(4.6)\end{array}$ & $\begin{array}{c}0.16 \\
(3.96)\end{array}$ \\
\hline
\end{tabular}

Values in parenthesis represent the heterobeltiosis (HB) in percentage; * Significant at $p=0.05$ and ** Significant at $p=0.01$.

Among 10 cross combinations (Table 7), the hybrids $\mathrm{HM} \times \mathrm{CRSP}, \mathrm{NH} \times 573$ (good $\times$ poor general combiners) and CRSP x 573 (good $\times$ good general combiners) for degree of sphericity; HM x BR1 and CRSP $x$ NH (good $x$ poor general combiners) for 
degree of porosity; CRSP $x$ HM (good $x$ good general combiners) and BR1 $x$ NH (poor $x$ poor general combiners) for geometric surface; CRSP $x$ NH (good $x$ poor general combiners) for seed height, were identified as good specific combiners. Results for heterosis over best parent (Table 7 ) revealed that only combination CRSP $\times \mathrm{NH}$ exhibited positive significant heterobeltiosis $(H B=10.4 \%)$ for seed weight while CRSP $\times$ HM and BR1 $\times$ NH cross showed a significant positive heterobeltiosis for geometric surface $(\mathrm{HB}=13.3 \%$ and $19.45 \%)$. For the degree of porosity, significant positive HB value was recorded in cross BR1 x HM (6.5\%). Two hybrids showed positive significant $\mathrm{HB}$ for degree of sphericity with values ranged from 22.1 (CRSP $x$ HM) to $23.3 \%(573 \times \mathrm{NH})$.

\section{DISCUSSION}

Significant differences amongst the ten pure lines for seed physical properties indicated the presence of diversity in the material. Variability for cowpea physical properties was also reported by Drabo et al. (1984), Taiwo (1998), Olapade et al. (2002), Lopes et al. (2003), Kabas et al. (2007), Noubissié et al. (2007), Yalcin (2007), Ajeigbé et al. (2008), Kaptso et al. (2008). When the physical properties values obtained in this research were compared with those of previous studies, they were within normal limits. Studying cowpea seed from Antalya (Turkey) at moisture content of $8.5 \%$, Kabas et al. (2001) noted an average porosity of $38.8 \%$, a sphericity of 0.77 , a surface area of $1.61 \mathrm{~cm}^{2}$ and a hundred seed mass of 20.5g. Ehlers and Hall (1997) noted that the existing variation for seed size in cowpea ranged between less than $10 \mathrm{~g}$ per 100 seeds and approximately $30 \mathrm{~g}$. Kaptso et al. (2008) pointed out that the seed weight, degree of sphericity and surface area in bambara groundnut were higher than in cowpea. The distribution of values of these physical properties for the tested population appeared to be continuous and suggested a quantitative inheritance for these traits. This supports the findings of earlier studies by Drabo et al. (1984), Lopes et al. (2003) and Noubissié et al. (2007). As reported by Lopes et al. (2003), Konak et al. (2007) seed physical properties are genetically controlled but the implementation of the program is affected by the environmental factors in particular moisture content and temperature (Rahman et al., 2005; Yalcin, 2007). Baryeh (2001) evaluated physical properties of Vigna subterranea seed as function of grain moisture content varying from $5 \%$ to $35 \%(\mathrm{wb})$ and observed in this moisture range, the 100 seed mass increased from $50.02 \mathrm{~g}$ to $80.06 \mathrm{~g}$, the grain surface area increased from 304 to $495 \mathrm{~cm}^{2}$, the sphericity decreased from 0.90 to 0.82 while the porosity increased non-linearly from 38.0 to $43.8 \%$ between $5 \%$ to $20 \%$ grain moisture and then decreased to $40.5 \%$ at $35 \%$. The same trends were observed in cowpea (Yalcin, 2007), in cotton by (Ozarslan, 2002), in sesame (Tunde-Akintunde and Akintunde, 2004), in vetch (Yalcin and Ozarslan, 2004), in safflower (Baumler et al., 2006) and in pea (Yalcin et al., 2007). Ajeigbé et al. (2008) observed that in cowpea, seed weight was positively correlated with dry seed hardness $(r=0.77)$ and crude protein content $(r=0.73)$ but negatively correlated with \% carbohydrate $(r=-0.78)$, final viscosity $(r=-0.84)$ and dry seed density $(r=-0.75)$. Selection for big seed will increase protein content and seed hardness but decrease carbohydrate content, viscosity and seed density. Knowledge of geometric surface would help in deciding the clearance between the abrasive surfaces for dehulling and would also help in designing the grader, cleaner and separator for the seeds.

The significance of the mean dominance deviation $\left(b_{1}\right)$ for all seed physical properties indicated that there is a non-directional dominance effects (Walters and Morton, 1978). Similar results were found by Lopes et al (2003) for seed weight. The significant $b_{2}$ item illustrated an uneven distribution of dominant genes among the parents for seed weight, surface area and sphericity, reflecting that some parents harbored considerably dominant genes than others. Dominant and recessive loci were not harmoniously distributed among the parents for these characteristics except the degree of porosity where symmetric of gene distribution was observed. The residual dominance $\left(b_{3}\right)$ which tests the part of the dominance unique to each $F_{1}$, was significant for all traits confirming the presence of specific dominance or combining ability in some crosses.

The significance of mean squares due to GCA and SCA showed the importance of both additive as well as the non-additive component of genetic variance for determination of these traits (Hayman, 1954). However, the magnitude of additive genetic component was more than the non-additive component as revealed by $\sigma^{2}$ GCA $/ \sigma^{2}$ SCA for all characteristics except the degree of sphericity in which the non additive component was higher. The preponderance of additive genes relative to dominance genes toward cowpea seed weight was particularly high expressive, characterizing an additive allelic interaction. Similar trends were 
reported by Lopez et al. (2003) and Hossain et al. (2010) who noted that the type of allelic interaction predominant between the genes that condition variability in cowpea seed weight is additive. Gupta et al. (1984), Rahman and Saad (2000), Rahman et al. (2005) also found positive and significant additive genetic effects for seed weight of Pisum sativum, Vigna sesquipedalis and Gossypium hirsutum respectively. This result is crucial for breeding programs because additive variance, which depends only on the contribution from homozygotes and can be fixed by selection, is the most important component in gain prediction expressions. When an additive allelic interaction is predominant, selection is facilitated, because superior individuals will produce superior descent. Rahman et al. (2005) observed that the patterns of inheritance for seed surface area in cotton were highly sensitive to the temperature and were controlled by additive genetic effects under heat stress conditions and by dominant genetic effects under non-stress regime.

Broad sense heritability values were high $(76 \%$ $96 \%$ ) suggesting that that the largest part of the observed variation of these physical properties was genetic in nature and the influence of the environment was smaller. Therefore, the possibility of obtaining a satisfactory selection gain is evident. High heritability values were also suggested for cowpea seed weight by Drabo et al. (1984), Lopes et al. (2003), Kabas et al. (2007). The estimated coefficients of heritability for other physical traits were within the limits found in previous studies (Noubissié et al. 2007). According to Lopez (2003) at least eight genes control seed size in cowpea. In chickpea, Hossain et al. (2010) revealed that seed size which is closely related to weight is governed by two major complementary genes, where small size is dominant. The values for heritability in narrow sense represented the percentage of total variation attributed to additive-nature genetic causes (Mather and Jinks, 1982). The high values of narrow sense heritability in diallel analysis $(0.67$ corresponding to $82.7 \%$ of genetic variation) for seed weight emphasized remarkably large additive effects. Hence, it might be possible to improve this trait by adopting pedigree method (Mather and Jinks, 1982). The occurrence of high values for narrow sense heritability indicated that the selection for seed size can be made in early generations. For seed surface, sphericity and porosity, the values of narrow sense heritability represented respectively $42.7 \%, 32.2 \%$ and $48.7 \%$ of the genetic variation, suggesting high influence of dominance gene effects particularly for sphericity. For all traits other than surface area, the average of degree of dominance $\left(H_{1} / D\right)^{1 / 2}$ was no greater than one suggesting partial dominance. The coefficients of regression of $\mathrm{Wr}$ on $\mathrm{Vr}$ were not significantly different for unity in seed weight $(0.96)$ indicating that the simple additive-dominance genetic model is adequate according to the assumption of Hayman (1954). However, in surface area of seed the coefficient $(-0.31)$ was significantly different from unity, suggesting the possibility of non-allelic interaction. The presence of substantial non-allelic interactions was also observed for seed surface area in cotton by Rahman et al. (2005). The regression analysis showed over dominance type of gene action for surface area but partial dominance for the degree of porosity and the percentage of sphericity. As overdominance type of gene action was present, selection based on seed surface area would be difficult in early generations.

The positive correlation between parental values $(\operatorname{Pr})$ and recessive factor $(\mathrm{Wr}+\mathrm{Vr})$ indicated that alleles for degree of porosity and sphericity were mostly recessive whereas the higher performances for seed surface where due to the presence of dominant alleles. The association of high porosity or sphericity percentage with recessive genes might present some difficulties for selection during the early generations. The coefficient of correlation between $\mathrm{Pr}$ and $\mathrm{Wr}+\mathrm{Vr}$ was positive but non significant for seed weight indicating the preponderance of a negative dominant gene control. Similar findings were reported for this trait in pea by Gupta et al. (1984).

Combining abilities reported could be biased by lack of independent distribution of genes in parental lines as a result of small number of lines used in this study. Despites the limitation mentioned above, information from this study is helpful in identifying best sources among the genotypes used. In general, there was a fairly good relationship between the GCA effects and per se performance of the parents for all traits except the geometric surface. For these traits, it is suggested that the per se performance of the parents could be reliable criterion for selecting parents for hybridization. Obviously, parents 573 and BR1 could be selected in hybridization programmes for improving seed weight and degree of sphericity while genotypes $\mathrm{NH}$ and $\mathrm{HM}$ could be utilized for increasing the degree of sphericity. Moderate magnitude of heterosis over best parent was recorded in certain crosses particularly CRSP $x \mathrm{NH}$ for seed mass, BR1 $\times \mathrm{NH}$ and CRSP $\times$ HM for the surface area of the seed, BR1 x HM for porosity, 
CRSP $\times$ HM and $573 \times \mathrm{NH}$ for sphericity. The superiority of hybrids over better parent indicated the parental combinations capable of producing the highest level of transgressive segregants (Fonsecca and Patterson, 1968). These hybrids can be exploited as basic material for breeding purposes. According to Mather and Jinks (1982), heterobeltiosis could be linked to one or two of the following situations: (i) the accumulated action of favourable dominant genes dispersed amongst two parents; (ii) the complementary interaction of additive dominant on recessive genes at different loci; (iii) favourable intra or inter locus interactions referred to as over dominance. Evidently, manifestation of HB might be due to the non-additive gene effects in the parents. It is noteworthy that the crosses, showing consistently positive SCA, also exhibited positive significant HB. The association suggested that HB could be useful for the choice of potentially more segregating populations in situation where SCA cannot be estimated. It is therefore suggested that SCA performance might be considered as a criterion for selecting the best crosses. The low $x$ low or low $x$ moderate general combiners exhibiting high SCA effects suggested gene dispersion and genetic interaction between favourable alleles contributed by both parents. Cross combinations involving poor combiners might be used through intermating in segregating generations and simultaneous selection for desirable traits. Inclusion of $F_{1}$ hybrids showing high SCA and having parents with good GCA, into multiple crosses, could be a worthwhile approach for tangible improvement of these seed physical properties.

\section{CONCLUSION}

Cowpea genotypes were highly variable for seed physical properties. These characteristics were controlled by additive and non-additive genes. For these traits, recurrent selection might be a useful breeding strategy. Improved methods to predict genetic gain and evaluate these quantitative traits without the environmental influence are also needed. Quantitative trait loci (QTL) may be targeted for future marker-assisted breeding strategies. In chickpea, Hossain et al. (2010) identified two major QTL that together accounted for $20 \%$ of the seed size trait.

\section{ACKNOWLEDGEMENTS}

The authors are grateful to Professor Ukai Yasuo of the University of Tokyo for providing the microcomputer program DIALL for the genetic analysis. They are also thankful to Mr Guidana of the
Department of Computers Science, University of Ngaoundéré for his guidance on data analysis.

\section{REFERENCES}

Ajeigbé, H.A.; D. Ihedioha and D. Chikoye (2008). Variation in physico-chemical properties of seed of selected improved varieties of cowpea as it relates to industrial utilization of the crop. Afr. J. Biotechnol., 7 (20): 36423647.

Baryeh, E.A. (2001). Physical properties of Bambara groundnuts. J. Food Eng., 47: 321-326.

Baumler, E.; H. Cuniberti; S.M. Nolasco and I.C. Riccobene (2006). Moisture dependent physical and compression properties of safflower seed. J. Food Eng., 72: 134140.

Ceyhan, E. (2006). Variation in grain properties of dry beans (Phaseolus vulgaris L.). Int. J. Agr. Res. 1(2): 116-121.

Drabo, I.; R. Redden; J.B. Smithson and V.D. Aggarwah (1984). Inheritance of seed size in cowpea (Vigna unguiculata (L.) Walp.). Euphytica, 33: 929-934.

Ehlers, J. D. and A.E. Hall (1997). Cowpea (Vigna unguiculata (L.) Walp). Field Crop Res., 53: 187-204.

Fonsecca, S. and F.L. Patterson (1968). Hybrid vigour in seven parent diallel cross of common wheat $(T$. aestivum L.). Crop. Sci., 2: 85-88.

Griffing, B. (1956). A generalized treatment of the use of diallel crosses in quantitative inheritance. Heredity, 30: 31-51.

Gupta, K.R.; R.S. Waldia; B.S. Dahiya; K.P. Singh and D.R. Sood (1984). Inheritance of seed yield and quality traits in peas (Pisum sativum L.). Theor. Appl. Genet., 69: 133-137.

Hall, E.A.; N. Cissé; S. Thiaw; H.O.A. Elawad; J.D. Ehlers; A.M. Ismail, R.L. Fery; P.A. Roberts; L.W. Kitch; L.L. Murdock; O. Boukar; R.D. Phillips and K.H. Mc Watters (2003). Development of cowpea cultivars and germplasm by the Bean/Cowpea CRSP. Field Crop Res., 82: 103-134.

Hayman, B.I. (1954). The theory and analysis of diallel crosses. Genetics, 39: 789-809.

Hossain, S.; R. Ford; D. McNeil; C. Pittock and J.F. Panozzo (2010). Inheritance of seed size in chickpea (Cicer arietinum $\mathrm{L}$ ) and identification of QTL based on 100 -seed weight and seed size index. Australian J. Crop Sci., 4 (2): 126-135.

Kabas, O.; E. Yilmaz; A. Ozmerzi and I. Akinci (2007). Some physical and nutritional properties of cowpea seed (Vigna sinensis L). J. Food Eng., 79: 1405-1409.

Kaptso, K.G.; Y.N. Njintang; A.E. Komnek; J. Hounhouigan; J. Schier and C.M.F. Mbofung (2008). Physical 
properties and rehydration kinectics of two varieties of cowpea (Vigna unguiculata) and bambara groundnuts (Voandzeia subterranea) seeds. J. Food Eng., 86: 9199.

Konak, M.; K. Carman and C. Aydin (2002). Physical properties of chick pea seeds. Biosystems Engineering, 82 (1): 73-78.

Langyintuo, A.S.; J. Lowenberg-DeBoer; M. Faye; D. Lambert; G. Ibro; B. Moussa; A. Kergna; S. Kushwaha; S. Musa and G. Ntoukam (2003). Cowpea supply and demand in West and Central Africa. Field Crop Res., 82: $215-231$.

Lopes, F.C.C.; R.L.F. Gomes and F.R.F. Filho (2003). Genetic control of cowpea seed sizes. Scientia Agricola, 60 (2): 315-318.

Mather, K. and J.L. Jinks (1982). Biometrical genetics. Chapman and Hall. London. 382p.

Maunde, F.A. ; M.A. Ali ; A. El-Okene and B.B. Riji (2007). Determination of physicochemical properties of cowpeas to aid thresher design. Advanced Materials Research, 18-19: 159-164.

Moshsenin, N.N. (1970). Physical properties of plant and animal materials. Gordon and Breach Science Publishers, New York, USA,

Noubissié, T.J.B.; Y.N. Njintang YN ; D. Ngakeu ; J.M. Bell and E. Youmbi (2007). Analyse génétique de quelques paramètres physico-chimiques de la graine chez Vigna unguiculata en zone soudano-guinéenne du Cameroun. In: Biotechnologies et maîtrise des intrants agricoles en Afrique centrale, Réseau Biotechnologies Végétales (BIOVEG). AUF, IRD, IRAD (eds). pp. 60-61.

Olapade, A.A.; G.I. Okafor; A.U. Ozumba and O. Alatunji (2002). Characterization of common Nigeria cowpea (Vigna unguiculata L. Walp). J. Food Eng., 55: 101105.

Ozarslan, C. (2002). Physical properties of cotton seed. Biosystems Engineering, 82 (2): 169-174.

Rahman, H.; S.A. Malik and M. Salem (2005). Inheritance of seed physical traits in upland cotton under different temperature regimes. Spanish J. Agricultural Research, 3 (2): 225-231.
Rahman, M.A. and M.S. Saad (2000). Estimation of additive, dominance and digenic espistatic interaction effects for certain yield character in Vigna sesquipedalis Fruw. Euphytica, 114: 61-66.

Singh, B.B.; H.A. Azeigbe; S.A. Tarawali; S. FernandezRivera and M. Abubakar (2003). Improving the production and utilization of cowpea as food and fodder. Field Crop Res., 84: 169-177.

Singh, K.K. and T.K. Goswami TK (1996). Physical properties of cumin seed. Journal of Agricultural Engineering Research, 64 (2): 93-98.

Taiwo, K.A. (1998). The potential of cowpea as human food in Nigeria. Technovation, 18 (6/7): 469-481.

Thakur, A.K. and A.K. Gupta (2006). Water absorption characteristics of paddy brown rice and husk during soaking. J. Food Eng., 75: 252-257.

Tunde-Akintunde, T.Y. and B.O. Akintunde (2004). Physical properties of sesame seed. Biosystems Engineering, 88 (1): 127-129.

Uhamaran, P.; R.P. Ariyanayagam and S.Q. Haque (1997). Genetic analysis of pod quality characteristics in vegetable cowpea (Vigna unguiculata L. Walp). Scientia Horticulturae, 70: 281-292.

Ukai, Y. (1989). A microcomputer program DIALL for diallel analysis of quantitative characters. Japanese $\mathrm{J}$. Breeding, 39: 107-109.

Unal, H.; E. Isik and H.C. Alpsoy (2006). Some physical and mechanical properties of black eyed pea (Vigna unguiculata L) grains. Pakistan J. Biol. Sci., 9 (9): 1797-1806.

Walters, D.E. and J.R. Morton (1978). On the analysis of variance of a half diallel table. Biometrics, 34: 91-94.

Yalcin, I. (2007). Physical properties of cowpea (Vigna sinensis L) seed. J. Food Eng., 79 (1): 57-62.

Yalcin, I. and C. Ozarslan (2004). Physical properties of vetch seed. Biosystems Engineering, 88 (4): 507-512.

Yalcin, I.; C. Ozarslan and T. Akbas (2007). Physical properties of pea (Pisum sativum) seed. J. Food Eng., 79 (2): 375-384. 